\title{
The effect of rapeseed and sunflower cakes on performance and composition of colostrum and milk in sows
}

\author{
W. Krasucki ${ }^{1,2}$, J. Matras' ${ }^{1}$ J. Solarz ${ }^{1}$ and E.R. Grela ${ }^{1}$ \\ 'Institute of Animal Nutrition, Lublin Agricultural University \\ Akademicka 13,20-934 Lublin. Poland
}

\begin{abstract}
Reproductive performance and composition of colostrum and milk were compared during two reproductive cycles on 36 sows fed soyabean, rapeseed or sunflower products. Total replacement of soyabean meal and oil during pregnancy, and partial replacement during lactation, by rapeseed cake and oil or sunflower cake and oil, did not affect reproductive parameters or colostrum and milk composition.
\end{abstract}

KEY WORDS: sow, rapeseed, sunflower, cakc, colostrum, milk

\section{INTRODUCTION}

Rapeseed and sunflower press cakes have higher fat and energy contents than the respective meals. In spite of their high fibre content they may be considered valuable substitutes of soyabean oilmeal (SBM) in sow diets. The increased fat content in sow diets can influence milk composition (Migdał and Kaczmarczyk, 1989; Schöne et al., 1998).

The objective of the study was to determine the effects of substituting SBM and oil with rapeseed or sunflower cakes and oils in sow diets on their reproductive performance and composition of colostrum and milk. SBM was replaced totally or partly in diets fed during pregnancy and lactation, respectively.

\section{MATERIAL AND METHODS}

The experiment was carried out during two reproductive cycles on 36 crossbred (Polish Landrace $\times$ Polish Large White) multiparous sows. The sows

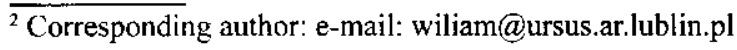


were mated with Duroc boars and allotted to 3 groups of 12 animals. During pregnancy, the animals from group I (control) were fed a standard diet containing $4.5 \%$ SBM and $1 \%$ soya oil whereas in the experimental diets, SBM and oil were replaced by $7.5 \%$ rapeseed cake (RPC) or $8 \%$ sunflower cake (SFC) fed to groups II and III, respectively. During lactation, the standard diet for the control group contained $18 \%$ SBM and 5\% soya oil. In the diets for experimental groups, SBM and soya oil contents were reduced and were supplemented with either $10 \%$ RPC and $4 \%$ rapeseed oil (group II) or with $10 \%$ SFC and $3.5 \%$ sunflower oil (group III). The diets were isoprotein and isoenergetic. SBM, RPC and SFC contained $44.3,29.9$ and $27.0 \%$ protein, and $6.7,10.3$ and $23.9 \%$ crude fibre, respectively. The RPC contained $14.9 \mu \mathrm{M}$ glucosinolates per g DM (Krasucki et al., 2004). Four sows were kept per pen during pregnancy, during lactation they were maintained individually. The animals were fed according to the Nutrient Requirements of Pigs (1993), feed intake was controlled. The sows were weighed at mating, before and after parturition. Piglets were weighed at birth, on days 21 and 28 of life (at weaning). Colostrum samples were taken from 6 sows on the first day of lactation and milk samples on days 7,14 and 21 .

Composition of milk and colostrum was determined according to standard methods. Fatty acids in feed, colostrum and milk fat were determined by gas chromatography on a GC 505 apparatus. The results were subjected to statistical analysis (ANOVA) using Statistica Software, Student's t-test.

\section{RESULTS}

As there were no significant differences between results obtained in two reproductive cycles, the means from two cycles are given. The mean body weight of sows at mating was $183.8 \mathrm{~kg}$, they gained on average $45.4 \mathrm{~kg}$ during pregnancy and lost $18.6 \mathrm{~kg}$ at parturition and $14.8 \mathrm{~kg}$ during lactation. The body weight gains and losses did not differ among the groups. The number and body weight of piglets on the first, $21^{\text {st }}$ and $28^{\text {th }}$ day of life also did not differ among the groups (Table 1). The fatty acid composition of oilseed products was typical. The diets did not affect the composition of milk and colostrum or the proportions of fatty acids (Table 2) except for a tendency towards a higher content of oleic and lower content of linolenic acids in both colostrum and milk fat of sows fed the RPC diet. Consequently, slightly higher MUFA and lower PUFA contents in colostrum and milk were found in this group. 
TABLE 1

Reproductive performance

\begin{tabular}{|c|c|c|c|c|}
\hline \multirow{2}{*}{ Item } & \multicolumn{3}{|c|}{ Group } & \multirow{2}{*}{ SEM } \\
\hline & SBM & RPC & $\mathrm{SHC}$ & \\
\hline \multicolumn{5}{|l|}{ Number of piglets } \\
\hline live-born & 10.84 & 10.60 & 10.51 & 0.32 \\
\hline day 21 & 10.42 & 10.16 & 10.08 & 0.44 \\
\hline day 28 & 10.16 & 9.86 & 9.72 & 0.29 \\
\hline Piglet mortality up to day 28 of life, $\%$ & 6.18 & 7.00 & 7.48 & 0.21 \\
\hline \multicolumn{5}{|l|}{ Litter weight, $\mathrm{kg}$} \\
\hline at birth & $\mid 4.41$ & 13.82 & 13.62 & 0.65 \\
\hline day 21 & 65.44 & 62.97 & 62.39 & 2.64 \\
\hline \multicolumn{5}{|l|}{ Body weight of piglets, $\mathrm{kg}$} \\
\hline at birth & 1.33 & 1.31 & 1.30 & 0.02 \\
\hline day 21 & 6.28 & 6.20 & 6.19 & 0.12 \\
\hline day 28 (weaning) & 7.73 & 7.55 & 7.48 & 0.31 \\
\hline
\end{tabular}

TABLE 2

Chemical composition of sow colostrum and milk, $g \mathrm{~kg}^{-1}$

\begin{tabular}{|c|c|c|c|c|c|c|c|c|}
\hline \multirow{3}{*}{ Item } & \multicolumn{3}{|c|}{ Colostrum } & \multirow{3}{*}{ SE.M } & \multirow{2}{*}{\multicolumn{3}{|c|}{$\frac{\text { Milk }}{\text { group }}$}} & \multirow{3}{*}{ SEM } \\
\hline & \multicolumn{3}{|c|}{ group } & & & & & \\
\hline & SBM & $\mathrm{RPC}$ & $\mathrm{SHC}$ & & SBM & $\mathrm{RPC}$ & Slic & \\
\hline Dry matter & 238 & 232 & 230 & 7 & 198 & 198 & 198 & 8 \\
\hline Crude protein & 116 & 113 & 113 & 3 & 56.4 & 55.4 & 54.6 & 2 \\
\hline lactose & 37.6 & 36.2 & 35.2 & 1.8 & 52.1 & 51.8 & 52.0 & 2.2 \\
\hline Crude ash & 6.8 & 6.6 & 6.4 & 0.2 & 8.3 & 8.1 & 8.2 & 0.2 \\
\hline Crude fat & 66.6 & 66.3 & 65.5 & 2.2 & 79.3 & 78.1 & 77.2 & 4.6 \\
\hline \multicolumn{9}{|l|}{ Fatty acids, $\%$} \\
\hline SFA & 35.4 & 34.7 & 34.8 & 2.6 & 38.9 & 38.7 & 38.6 & 2.8 \\
\hline UFA & 64.6 & 65.3 & 65.2 & 2.3 & 61.0 & 61.3 & 61.4 & 2.8 \\
\hline MUГA & 44.9 & 46.6 & 45.3 & 1.9 & 45.3 & 46.4 & 45.7 & 2.1 \\
\hline PUFA & 19.7 & 18.7 & 19.8 & 1.2 & 15.8 & 14.9 & 15.7 & 0.9 \\
\hline$n-6$ PUFA & 18.7 & 17.5 & 18.9 & 1.4 & 14.6 & 13.7 & 14.7 & 0.3 \\
\hline$n-3$ PUFA & 0.98 & 1.03 & 0.92 & 0.15 & 1.12 & 1.18 & 0.96 & 0.14 \\
\hline n-6/n-3 PUFA & 19.1 & 17.0 & 20.5 & 1.5 & 13.0 & 11.6 & 15.3 & 0.8 \\
\hline
\end{tabular}

\section{DISCUSSION}

The oils differed in fatty acid profiles, with the most favourable n-6 to n-3 proportion in rapeseed. The results obtained in the group fed the diet with rapeseed cakc are similar to those reported by Schöne et al. (1998), who, giving $40 \mathrm{~g}$ rapeseed oil or $100 \mathrm{~g}$ full-fat rapeseed per $1 \mathrm{~kg}$ sow diet, did not find any effect on the number or weight of piglets. There are no available publications on 
the use of sunflower cake in sow nutrition. The introduction of rapeseed fat to the sow diets usually increases the UFA content in colostrum and milk (Migdat and Kaczmarczyk, 1989). Despite the substantial differences in the fatty acid composition of the oils used (soyabean, rapeseed, or sunflower), the changes in fatty acid composition of colostrum and milk were not large. It may indicate the importance of fatty acids synthesis in the mammary gland.

\section{CONCLUSIONS}

The entire (pregnancy) or partial (lactation) replacement of soyabean products $\left(\mathrm{SBM}^{-}{ }^{-}\right.$soyabean oil) in sow diets by the other seed oil products, rapeseed (RPC+rapeseed oil) or sunflower (SPC+sunflower oil), did not significantly influence sow reproduction indices or colostrum and milk composition.

\section{REFERENCES}

Krasucki W., Matras J., Solary J., Grela I .R., 2004. Influence of rapeseed and sunflower cakes in gestation and lactation diets on some blood indicalors of sows. Rocz. Nauk. Zoot., Suppl. 20. $111-114$

Migdał W., Kaczmarczyk J., 1989. Chemical composition of lipid fraction of the colostrum and milk of sows fed rations with rapeseed oil. Acta Agr. Silv., Ser. 7oot. 28, 93-103

Nutrient Requirements of Pigs. Nutritive Value of Feeds (in Polish), 1993. The Kielanowski Institute of Animal Physiology and Nutrition (Editor). Jabłonna (Poland)

Schöne F., Hartung H., Jahreis (i., Graf 'T., Tischendorf F., 1998. Evaluation of high fat rape feeds (seed+cake) on breeding sows-feed intake, rearing results and milk fat composition. J. Anim. Physiol. Anim. Nutr. 79, 184-197

\section{STRESZC7.FNIE}

Wplyw makuchu rzepakowego i słonecznikowego na reprodukcję oraz skład siary i mleka loch

Przeprowadzono badania w 2 cyklach reprodukcyjnych na 36 lochach, podzielonych na 3 grupy. Porównano wpływ stosowania w dawkach produktów przemysłu olcjarskicgo, pochodzących z przetwórstwa soi, rzepaku i słonecznika na wskaźniki reprodukeyjne loch oraz skład siary i mleka. Całkowite (cią̧a) lub čęściowe (laktacja) zastapienie w mieszankach produktów soi (śruta sojowa pockstrakcyjna + olej sojowy) produktami z rzepaku (makuch - olej) lub słonccznika (makuch + olej) nie zmieniło istotnie parametrów reprodukcji ani składu kwasów thuszczowych siary i mleka. 